ARTICLE

https://doi.org/10.1057/s41599-018-0207-4

\title{
Hexing the discipline: against the reproduction of continental philosophy of religion
}

Marika Rose ${ }^{1} \&$ Anthony Paul Smith ${ }^{2}$

\begin{abstract}
There has been a generalised anxiety concerning the future of continental philosophy of religion as a discipline, with a number of books, articles, conferences, and presentations taking up this theme. This anxiety exists because as a discipline continental philosophy of religion lacks a clear claim to an identity. This article analyses the anxiety concerning the future of continental philosophy of religion as an anxiety of reproduction. By locating the philosopher's anxiety within a wider anxiety of reproduction we begin to understand this anxiety through the queer anti-social critique of Lee Edelman. This anxiety is traced through three processes of reproduction: intellectual reproduction, disciplinary reproduction, and institutional reproduction. The article goes on to sketch out a position against the reproduction of continental philosophy of religion by taking on and celebrating the discipline's improper nature. Appealing neither to secular reason nor to established traditions, we draw on the Malleus Maleficarum (as read through queer theory and non-philosophy) to craft various models for thought. Here we find abortion prized over the future of the race, miscegenation over blood purity, and impotence and infertility over the sovereign power of the father. These models are explored both in terms of their historical context and as providing a different image of the work that can be carried out in the discipline of continental philosophy of religion. The article concludes by suggesting other perverse lines of relation that may be opened up when one gives up on the reproduction of the discipline.
\end{abstract}

\footnotetext{
${ }^{1}$ University of Winchester, Winchester, UK. ${ }^{2}$ La Salle University, Philadelphia, USA. Correspondence and requests for materials should be addressed to M.R. (email: marika.rose@winchester.ac.uk)
} 


\section{Introduction}

o hear people talk, no one much cares for the present. Everything is a program 'for the future', a time that is said to be on the way, to be coming, and that dominates and harasses us now. 'Plan for the future', comes the demand, 'Plan for me'. That rush of panic and fear, lying in bed, holding another in your arms, no longer in the moment, but thinking, 'How are we going to afford this?' The moment of impropriety gives itself over to propriety and the concern for property. The embrace of a lover is given over to the reproduction of the species, to the continued world-building and world-sustaining project of a forever deferred future that requires the undermining and the deferral of pleasure now.

This concern with the future is not only a matter of love and romance, but structures all our endeavours, including our intellectual attempts to make sense of the world we have been thrown into. To speak of the future is to speak speculatively, so to speak of the future is to do philosophy. The question before us now is that of the future of continental philosophy of religion, but before such a question can be answered we have to analyse what is really being asked. To speak about the future of a discipline is to speak about its reproduction. Subsequently, to ask what is the future of continental philosophy of religion is really to ask, how will continental philosophy of religion reproduce itself?

Too often philosophers and theologians consider their disciplinary practices only as abstracted from the material conditions which structure this intellectual labour. This occlusion of the material realm allows for a spiritualisation of work that mirrors the new spirit of capitalism found in the neoliberal university. It also allows for the question to be asked as if it were a concern for the other, the future that is not ours or not mine, but rather that of 'the Child' (Edelman, 2004). Within the symbolic register, the Child appears as other but is in fact constituted by a disavowed desire for more of the same. One is concerned with the Child as the product of the Father and the Mother, as the reproduction of their genes in new form. In the same way that the reproduction of self through the Child functions as the sexual form of our social ontology, asking about the future form of a discipline is a disavowed way of asking about that discipline's survival as our discipline. What have we been doing with our lives if all of it comes to nothing, we might be tempted to ask during those dark nights of the soul that haunt academics in the humanities. Yet the better question is, why do we want something rather than nothing anyway? What if we could get what we want for nothing? ${ }^{1}$

This will surely strike the reader as a strange question, as a reversal of the usual philosophical question of why there is something rather than nothing. We hold that this question reveals truths about the deep structure of continental philosophy of religion, and such philosophical/theological projects more generally. We argue that any consideration of the future of continental philosophy of religion must take it seriously as an institutional practice which relies on and reproduces relations of property and propriety. These reproductive practices take place at the intellectual level, the disciplinary level, and the institutional level. At the intellectual level, ideas are reproduced in texts and through citational practices; at the disciplinary level, intellectual and social norms are reproduced through social and pedagogical relationships; and at the institutional level, academics reproduce both social class and the university itself. To understand these processes of reproduction we build on existing scholarship, usually critical, of the university. Rather than aiming to add to these critiques, we gather them together to provide the context for the constructive project that follows.

After unpacking and analysing each of these forms of reproduction, we ask whether thinking from the abortion rather than the reproduction of continental philosophy of religion might reveal the constitutional duplicity of continental philosophy of religion. As a discipline, continental philosophy of religion is improper: neither wholly Christian, nor fully secular. As such, two models of reproduction are available to it: filial transmission of paternal inheritance or fraternal denial of filiation. Against both options, we propose to exploit the impropriety present in continental philosophy of religion so as to bewitch the discipline. In this bewitched state we are easily led towards more radical practices of thought that are wilfully negligent of their own reproduction. Appealing neither to secular reason nor to established traditions, we draw on the Malleus Maleficarum to craft various models for thought. We read the Malleus Maleficarum through queer theory and develop it into what François Laruelle terms 'philo-fiction'.' Here we find abortion prized over the future of the race, miscegenation over blood purity, and impotence and infertility over the sovereign power of the father.

\section{Processes of reproduction}

Thinking continental philosophy of religion. As Carol Pateman argues, the birth of modernity is marked by the transition from a paternal model of inheritance and reproduction to a fraternal denial of filiation which continues the tradition of patriarchal power in the form of the claim to escape paternal authority (Pateman, 1988, pp. 2-3). This shift may also be understood as the transition from the political theological structure of medieval Christendom, whose authoritative structures and traditions were understood to be handed down unchanged from the Fathers to the secularised insistence on the sovereignty of the individual. It entailed, that is to say, the transposition of characteristics which had previously been attributed to God onto the individual subject, understood to be (at least potentially) self-grounding, all-powerful, and all-knowing. We may also understand it in relation to the secularising move in which the West repeats differently the original move by which Christianity invented both itself and religion. Where the birth of Christianity was made possible by the denial of filiation (such that there is in Christ no longer Jew nor Greek but only Christians, set up against those who remain outside of Christ and therefore salvation) (Anidjar, 2014, p. 254), so too the secular was born from the cutting of the umbilical cord which tied the secular West to its own particular Christian history, emancipating itself from religion, amongst other forms of dependency which come to be conceived in opposition to the selfgrounding freedom of the properly human subject (Barber, 2011, p. 111).

Continental philosophy of religion has long been characterised by a fraught relationship to these two models - paternal and fraternal, Christian and secular. Perhaps the starkest examples of this are, on the one hand, those who see the goal of continental philosophy of religion being to call Christianity's wayward children back to the fold, demanding that they faithfully honour their inheritance with the threat that, should they fail to do so, they will be left in the pigsty with nothing; or those for whom continental philosophy of religion must, to come of age, emancipate itself from its degenerate forebears.

But these forms of reproduction extend beyond the question of continental philosophy of religion's relation to religion (or, as this so often means in practice, to Christianity and Christendom), and concern also the discipline's relation to philosophy. Continental philosophy is distinguished in part by the ways it is both consciously and unconsciously genealogical, formed as a discipline precisely by its relation to a particular tradition of thought; constituted as an ongoing conversation whose deep engagement in ongoing traditions of thought are one of the reasons it is so often characterised as "difficult". Its attention to 
questions of power and its genealogical approach are set up in some ways in opposition to the tendency of modern thought to abstract itself from history and from genealogy, and its critical force derives from this insistence on paying attention to the history of the thinkers and ideas with which it concerns itself. But this focus on tradition is also crucial to the ways in which it reproduces itself. To engage in the task of continental philosophy is to be expected to have read everything, to have mastered the conversation, to be able to position oneself in relation to historical debates and tendencies; and this insistence on knowing one's family history functions not only to enable critique but also (as with so many forms of academic specialisation) to limit it. Who has time to read not only in their own immediate area of work but also outside of it, to understand not only what is at stake in the differences between Deleuze and Derrida but also to bring those thinkers into productive encounter with Black Studies? Continental philosophers constitute a large and a fractious clan, but like so many close extended families the demand for participation works to ensure the reproduction of kinship.

Yet the way out of this bind cannot simply be to seek to escape filiation. Just as the fraternities of medieval Europe sought a form of life free from the ties of kinship and reproductive labour but relied on the unacknowledged and salvifically worthless work of women and peasants, so too the fraternal form of sovereignty on which modernity founds itself is built on the invisibilised labour of slaves, women, and the working class. Continental philosophy shares this desire to escape dependency, understood as a limit to freedom; ${ }^{3}$ to deny its origins and to erase the racialised, gendered and classed work which makes it possible (Irigaray, 1985; Barber, 2011; Bousquet, 2008) so as to position itself as self-sufficient, free and enlightened. This denial of inheritance can also function as the desire for innocence; the desire to leave behind a shameful past or move towards a better future; as the desire for conversion into something better which itself functions to reproduce the world (Barber, 2016) and to reproduce the logics of the discipline.

Disciplining continental philosophy of religion. Loath though we are to acknowledge this, continental philosophy of religion does not exist solely in the minds of those who practice it. Ideas must circulate, and circulation requires economies-of money, prestige, and social connections. Continental philosophy of religion is, amongst other things, an apparatus composed of texts (book series, monographs, edited collections, journal articles, blog posts, emails, social media posts), events (conferences, symposia, lectures, seminars, meetings), people (publishers, editors, peer reviewers, professors, students, enthusiasts) and institutions (universities, publishing houses, conference centres, networks, funding bodies). It needs-perhaps above all else-to keep itself going, to reproduce itself as a discipline, to assure its own future.

Academic disciplines emerged first with the birth of the university, and alongside the many forms of classification which created by carving up the world into new distinctions of race, nation and class at the birth of the modern world (Federici, 2004; Wynter, 1994; Moore, 1987). Traditional academic disciplines are -like the prisons, factories, schools and madhouses of Foucault's disciplinary power-clearly contained, controlled and observed.

A later birth, continental philosophy of religion is perhaps a quintessentially postmodern-that is to say, a post-Fordist, control society, late capitalist, neo-imperialist, liberal democratic discipline-and its disciplinary practices reflect this. Doubly improper, both as philosophy and as religion, continental philosophy of religion often finds itself at the edges of academic economies of power and prestige, relying on more informal (though often no less violent) networks for its propagation. Perhaps it is this very impropriety which makes the discipline so eager to mark out its terrain and to assert its patrimony. ${ }^{4}$ Much ink has been spilled on the topic of the future of the continental philosophy of religion; yet as within the university in general there is comparatively little discussion of the material conditions in and by which the discipline assures its future. Who decides which books are to be published, who is to be hired, which junior scholars are to be protected from the violence of precarity? These questions and concerns are not mere abstractions, but concern real people who-however much we value their work or the traditions they have come to symbolise-are part of the very reproduction of society and so have interests that are shaped by their gender, class, and racial position within the world.

Institutionalising continental philosophy of religion. If the disciplinary practices which ensure the reproduction of the continental philosophy of religion too often go examined, questions of the role of continental philosophers of religion within the institution of the university are all but invisible. This is perhaps unsurprising within a system in which those most able to publish are also those with access to the most resources, those most able to imagine themselves, like medieval monastics, as living the pure life of the mind. For those further down the hierarchy, scrambling to survive precarity and ever-increasing teaching and administrative loads, the demands of the university are more pressing but can seem, nonetheless, like a distraction rather than the real purpose of our work.

The university is a central apparatus of the persecuting society which the West became over the medieval period (Moore, 1987); it is a machine for the creation and reproduction of race, class, and gender (Moten and Harney, 2004). To work in the university is, therefore, to reproduce ourselves as the intellectual class; to reproduce the 'ideas of the ruling class'; to reproduce the university as a profit-generating, market-sustaining and borderguarding machine; and to be charged with the reproductive labour by which teenagers complete their transformation into neoliberal subjects (Marx and Engels, 2000; Brown, 2015; Bousquet, 2008). As tempting as it is to believe ourselves the vanguard of the radical university, to become incorporated into the university machine is to become materially invested in the reproduction of the university as institution and of ourselves as experts. No wonder that when the chips are down we are so often willing to call in the cops, take the knife to our colleagues' pensions, or side with our peers against our students (see, e.g., Grove, 2015; Payne, 2018; Nancy, 2018).

For many of us, perhaps the majority, our most important audience is not our academic peers, 'the public' or even 'the Church', flattering though this might be to believe. Instead, our most important work is done in the classroom. Teaching is social reproduction, and carries with it the profound ambivalence of all reproductive labour: to form our students into good citizens and useful workers for a society built on violence and exploitation. Often this involves training them (sometimes despite our best efforts) in the fundamentally conservative moral relativism so essential for workers in an economy which prizes flexibility above all else; ultimately our task is to teach them how to survive in a world which ought not to exist.

The university is a central cog within local economies, border regimes, and mechanisms of class discipline. Administrative work may feel like a distraction-and may in fact function to distract us from the difficult work of understanding the university in order to work against it-but what we do in meetings, the forms we fill out, the monitoring and assessing work we do forms us, our students, and the university as an institution. As the implementation of the Prevent strategy in British universities exemplifies, there is no way to care for our students that does not also enmesh 
them in systems of monitoring which exist to reproduce the world which puts them to work for its own purposes (Lister et al., 2015; Kundnani, 2015). We cannot engage in institutional or strategic planning without keeping alive the university as a source of violence.

There is no such thing as a radical university; there is no straightforward experience of teaching as liberation or of administration as revolutionary. To survive in the university is to co-operate in its reproduction, to work with it even as we struggle also to work against it, to reproduce it precisely by our longing for something better. What would it mean to take responsibility for this inescapable complicity?

\section{The transmogrification of continental philosophy of religion}

The Malleus Maleficarum, the medieval manual on the nature, practices and prosecution of witches was first published in 1486 and for almost two centuries was the second-bestselling book in Europe after the Bible. Written at the beginning of the modern era, its European influence spanned a period which saw the birth of biopower, the European discovery of the Americas, the emergence of the nation state, and the formation of the social contract. Its authors-Dominican priests, professors of theology and zealous inquisitors-exemplify the entanglement of church, state, and university which prevailed in late medieval Europe. Written during apocalyptic times, it seeks to stave off the collapse of the social order by setting out a framework for theorising, investigating, and prosecuting witches, whose transgressive behaviours are understood to threaten social reproduction. At the heart of the text are profound anxieties about women, gender and reproduction which reflect the dramatic transformation in the gendered organisation of society taking place at the time of the Malleus Maleficarum's writing. Women, according to Kramer and Sprenger, are naturally less moderate, more prone to belief, more changeable, more gossipy, and less perfect (Kramer and Sprenger, 2009 , p. 160-165). Less able than men to resist the lures of the devil, they threaten not only the present but above all the future; drawing on demonic powers to make men impotent, to cause miscarriages or abortions, to devour or dedicate to the devil newly born children, or to change their shape. The theories, practices and procedures the Malleus Maleficarum lays out illuminate the disciplinary practices emerging in European states in this period, which came to be crucial resources for the dramatic transformations of the organisation of race, class and gender on which the modern world was built. The text suggests itself as a resource for contemporary thought for a number of reasons: it embodies the profound entanglement of the late medieval university with emerging biopolitical practices; it seeks to hold together Christian and secular thought during a period where the two were becoming increasingly distinct; and it reflects social, theological and philosophical anxieties about reproduction. What we find in the Malleus Maleficarum is not a faithful account of contemporary pagan practices but, instead, a projection of the anxieties which drove the transformation of nascent European state power. The witches of the text are not faithful renditions of real people or practices but, rather sinthomosexual figures in Lee Edelman's sense (Edelman, 2004): embodiments of the unassimilable excess generated by the contemporary social order, hallucinatory figures of the pleasure understood to threaten proper social discipline.

From within the West, there is no simple outside to the Christian, or to the secular which repeats the logic of Christianity. As for so many gnostic, heretical, or pagan threats to Christianity, what we know of medieval witches comes to us not pure (as though there could be some pure outside to Christianity within medieval Europe), but as a distortion and a hallucination from within Christianity. Likewise, there is no escape into propriety for the continental philosophy of religion, which is marked always by the impropriety of the religious, by the impropriety of the overdetermination of the religious by the Christian, and by the impossible desire to escape that impropriety.

What we propose, then, is not escape but instead an intensification of witchcraft's impropriety, to inhabit and affirm its excess with respect to the proper. Women, according to Kramer and Sprenger's false etymology of their Latin name, femina, are those who have by nature 'less faith' ('fe' and 'minus'). Witchcraft is not entirely an escape into the innocence of faithlessness, then, but consists of the possibilities opened up by believing less, not quite trusting in right belief enough to guarantee its reproduction (Kramer and Sprenger, 2009, p. 165). Within the material conditions of the modern university and its social ontology, the continental philosopher of religion will continue to be a structural remainder to proper reproduction-neither fully theological and thereby Christian, nor fully secular; neither properly faithful nor properly faithless; simply not proper. Continental philosophy of religion, at its best, concerns itself with the improper elements of both the theological and the secular: not only with God but with angels and demons, heaven and hell, thinking according to an improper logic which refuses simply to affirm or to deny their ontological reality; not only with the mystical purity of thought but with the seeping bodies and questionable practices of the mystics. We turn here to witchcraft and to the Malleus Maleficarum, then, not to escape Christianity or to purge continental philosophy of its embarrassing desire for doctrinal propriety, but in order to interrupt, disrupt, or distort the reproduction of the continental philosophy of religion for the sake of the pleasure of thinking.

Impotence. Modern readers of medieval witchcraft treatises will surely be surprised at the constant fear present of witches stealing penises. One does not need an advanced education in Freud's theories of the psycho-sexual development of men to see and understand the deep anxieties of the fragile masculine ego and patriarchal power at the root of these stories; but the psychoanalytic framework, especially as developed by queer theorists, allows for a more finely tuned analysis of these anxieties. The authors of the Malleus Maleficarum go to great lengths to push back against the magical thinking found within witchcraft. They tell us that, of course, witches cannot actually take away "male members," but they can make them appear to disappear through conjuring (Kramer and Sprenger, 2009, p. 195). The reasons why the authors need to secure the reality of the penis against its apparent disappearance are rooted in a commitment to a form of metaphysical realism common amongst Dominican theologians of the time. Quite simply, they tell us, demons cannot take away that which contributes to the reality of the human body. So disappearing penises are illusory, though not just illusions in the imagination of the person affected. Others may share in this illusion, which demons and their witches carry out through deceiving a person's physical senses and sometimes their inner senses of perception (Kramer and Sprenger, 2009, p. 195). The authors go on to explain the various methods available for bringing about these illusions, which run the gamut from banal sleight of hand tricks, to non-consensually drugging men so that they hallucinate the loss of their penis, to psychic deception by a demon carried out only with God's permission (Kramer and Sprenger, 2009, p. 198).

There is a deeper truth here that is surfaced but repressed by the authors. While it may have been true that the disappearing of penises was mere illusion this is not because, as the authors claim, these penises eventually reappeared and so their disappearance 
was not permanent (Kramer and Sprenger, 2009, p. 199). Rather, the disappearing of these penises was and is illusion because the penis itself is an illusion. We do not mean that the bodily organ is an illusion, but that all of what is caught up in the symbolic meaning of the penis-what is known in psychoanalysis as the phallus-is an illusion.

The stealing of penises by witches is, on our reading, the paradigmatic example of how witches bring about impotence. The anxieties around reproduction revealed by Kramer and Sprenger's writing about impotence appear to centre on the question of authority and power, specifically male power. To be impotent is literally to be lacking in power, specifically with regard to the sexual act and so with regard to reproduction. They report a number of forms of impotence, drawing largely on Peter de Palude's Commentary on Sorcery, where impotence centres around the prevention of 'bodies approaching one another' either through direct or indirect means (Kramer and Sprenger, 2009, p. 194). Witches and demons may work together so that men want to have sex with the wrong kind of woman or do not want to have sex with the right kind of woman, through various appeals to estimation and imagination, making some women appear loathsome, and even through direct physical means-suppressing the erection of the penis or halting the progress of semen (the seed) along the vessels of procreation. Yet in each of these cases, while Kramer and Sprenger recognise the same actions may be taken with regard to women, such as removing their desire for their husbands, it is easier to suppress the erection of the penis than anything else and so men are more vulnerable than women to being rendered impotent by such witchcraft.

In Lacanian psychoanalysis the phallus takes on a particular character as split between the overarching tripartite structure of the real, the symbolic, and the imaginary. For Lacan, the imaginary phallus emerges prior to the oedipal stage where it is understood by the child as an "image of the penis" where the organ is a part-object that can be removed. The child infers an image of the phallus specifically as the object of the mother's desire beyond the child and so the child seeks to identify him or herself with this object of desire. In other words, the child wants to be the phallus of the mother. The child cannot be this phallus and this is the castration that the child must accept in order to develop beyond this stage.

At this point the phallus changes status from imaginary to symbolic. Important for our reading here is that the symbolic phallus is no longer taken as a part-object, but now 'is a signifier [...] It is the signifier intended to designate as a whole the effects of the signified' (Lacan, 2006, p. 285). The symbolic phallus is taken as a kind of securer of meaning, the meta-signifier that makes possible the relationship of signifier and signified. In other words, the symbolic phallus functions in much the same way as does theodicy in the Malleus Maleficarum, where the experience of evil is placed within an overarching structure of God's sovereignty that secures the very meaning such evil threatens to undo.

Anxiety of impotence lies behind many of the anxieties produced by the reproductive structure of continental philosophy of religion. The magical theft of penises becomes, then, a model for continental philosophy of religion that philosophers of religion may use to release ourselves from the rule of the phallus and its phantasmic fundamental place in reproduction. The phallus-again taken here as the name for what, like the male penis, passes on the seed of the discipline-is also taken as the fundamental image for doing philosophy in a powerful way. Instead of this drive towards power, particularly power understand in such a unitary and rigid way, thinking according to impotence provides a model of doing continental philosophy of religion without concern for such engorged forms of power.
We steal penises-that is, we steal those elements of philosophy that are taken to be precious, to be the very location of a philosopher's rigid power-so as to expose those objects or those ideas for the fundamentally fungible reality they are. Instructive here is a bizarre and hilarious story in the Malleus Maleficarum. Kramer and Sprenger report that a man woke to found his penis missing and went to the local witch in order to ask for it back. Though Kramer and Sprenger do not offer insight into the reason why the witch took pity on the man, she tells him that he may climb a certain tree and find a nest full of penises from which he could take any he wanted. When he attempted to take a particularly large one, the witch counselled against this as it belonged to the local priest.

This witch is said to be like many others who keep 'large numbers of these members (20 or 30 at once) in a bird's nest or in some cabinet, where the members move as if alive or eat a stalk or fodder' (Kramer and Sprenger, 2009, p. 328). Of course, for Kramer and Sprenger these gaggles of penises are only an illusion, for the physical penis had not truly been removed. This works all the better for our model, since the kind of phalluses we are speaking of are those overarching ideas that shape the relation of a philosopher to other philosophers and of this group of people to the discipline itself. The witch returns us to the preoedipal stage of development wherein the penis is taken as a part-object, one that can be removed and used differently than it comes to be intended when our sexuality settles and solidifies upon certain bodily organs. Instead of being the signifier of the whole, it becomes just another thing to work with or play with, just more material. We might make a nest out of them or we might plant one or two in the ground and see what happens. We will not, however, centre our entire identity upon the phallus; it is no longer allowed to drive the reproductive practices of the discipline.

Let us translate this witchy model into more everyday language. So much of the anxiety of intellectual work is centred around one's power, taken in this particular rigid way. Much of the intellectual work of continental philosophy of religion is undertaken with an eye towards its impact or, ultimately, its meaning, for a particular community. Is the meaning of continental philosophy of religion found in its Christian identity or its secular identity; and which identity will we be able to pass on? The answer, once we are freed from the underlying desire for meaning, for the underlying desire that there be something to pass this work on to, is that there is no meaning, at least not in the necessary sense.

Is our hope in nothing? Well, yes. When we give up on the desire to secure a future for our intellectual work, we can give ourselves over to a joy in the work for its own sake. When, as the subject who can now look upon the phallus as a fantasy, then we see that we do this work for nothing. Such a claim need not be understood as nihilistic in the sense that a scientific worldview reveals there to be no inherent meaning in the universe. It may be thought instead, through some of the mystical traditions which have deeply formed the continental philosophy of religion. The mystical conception of nothing we are drawing on here is metaphysical, such that even at the heart of the meaning of nothingness there is a further undoing of meaning (Dubilet, 2019; Rose, 2019). Such a metaphysical nothing should not be confused with the ever growing demand for free labour from academics. There is no way to extract wealth from this nothing, which unmoors us from the world and its demands to reproduce, and in fact such a non-phallic conception of work would encourage one to think beyond the engorging of power with a singular purpose and encourage a more diffuse form of strength without concern for its reception. 
Miscarriage and abortion. Of course, conception is no guarantee of reproduction and the anxieties of the Malleus Maleficarum's authors do not begin and end with male potency. The intensification of European anxiety over the control of reproduction which began in this period is clearly evident in the text. Located as it is in Europe, the primary focus of the author's concern is the safe gestation and birth of infants rather than, as became increasingly important once the colonial and racist logics incubating here were more fully birthed, the desire to hold back the threat of the dark swarming hordes of the wrong kinds of babies. If white children are to have a future they must be allowed to come to term, and women's bodies must be expropriated from them so as to be '"liberated" from any impediment preventing them to function as machines for the reproduction of labour' (Federici, 2004, p. 184). At stake here is not merely the reproduction of individual family units, but also of the larger bodies whose regulation and control becomes a pressing concern in this period, characterised by the invention and intensification of evermore tightly regulated borders marking the proper terrain of both nation states and academic disciplines.

Like so many fathers, neither philosophy nor the academy has ever had much time for children, and while celibacy is no longer a requirement for entry it continues to be understood that we will give our energy, time and bodies over to the production of books, disciples, and Festschrifts. The higher our status, the less we have to concern ourselves with the reproductive labour of preparing other people's children for adult life and the more with our own legacy and the preservation of disciplinary propriety-we are to be, Doktorväter rather than Doktormütter.

According to Lacan, the university discourse-that is, the social formation of desire best exemplified by the capitalist universityis driven by the endless injunction to produce, a demand so insistent and relentless that we are left unable to direct our energies towards the question of how the social formation we inhabit might be transformed. Our disciplinary labour is multiply productive, functioning to generate profit both for academic publishers in particular (including, of course, the publisher of this journal) and for capital more broadly; ${ }^{5}$ but also to effect the real subsumption of our desire and energy-our souls-into the neoliberal logics of endless (re-)production and ceaseless selfimprovement such that we are too busy, too tired, and too anxious to stop, to think, to refuse.

A resident of Bormio, the Malleus Maleficarum recounts, on finding his child lost went in search of it and found 'a gathering of women at night time', amongst whom 'the baby was being killed and eaten while liquor was being consumed' (Kramer and Sprenger, 2009, p. 212). Fortunately, Kramer and Sprenger reassure us, the local authorities responded promptly and saw to it that forty-one sorceresses were 'consigned to the flames' while others fled the region. Contemporary academia is all too familiar with the threat of women conspiring for the destruction of the fragile disciplinary future, although a turn of the screw has us worrying, in this age of \#MeToo, less about witches than witch hunts. As Edelman argues, the Child-the figure of the vulnerable future for whose sake we must fall in line and commit to reproducing the world as it is - signifies not the youngest and most vulnerable but the investment of the powerful in assuring the continuation of their own power. To put this child to death, to murder it in the womb or leave it on a hill to die is to refuse to sacrifice our selves, our bodily autonomy, our own power for the sake of our future careers, for the reputation of our heroes, for the promise of prestige. But these acts of refusal and destruction are dangerous when undertaken individually. 'More [women] were executed for infanticide in 16th and 17th century Europe than for any other crime, except for witchcraft' (Federici, 2004, p. 88-89); and individual acts of refusal, from naming abusers, refusing to be complicit in institutional cover-ups, or simply failing to be sufficiently productive, bring forth more often the destruction of the individuals concerned than any final transformation of the institutions, as Jason Reitman, Sara Ahmed, Jim Newell and others could no doubt testify (Chu, 2018; Ahmed, 2016; Rigg, 2018). The great success of the late medieval witch hunts was not merely in the prosecution of individuals, but the successful expropriation knowledge and skills which had once been collectively held. To begin to work towards the miscarriage or abortion of our disciplinary futures must be, then, not simply to enjoin individual acts of boldness but to forge new forms of collective power and resistance in, around and despite the structures of institutions which seek to divide us from one another even as we are enjoined to sacrifice everything for a collective future which will never be ours.

Devouring the child or offering the child to the devil. Sensitive readers may ask how it is we can claim to be against the future, even in the small sense of being against the reproduction of a discipline. Given the state of the world we find ourselves living in, how could we possibly be against the future for which past generations mortgaged their present? We are against the future as the symbolic term that subverts and subjugates the now that we live in. Our sympathy with witches extends beyond the humorous (stealing penises so as to reveal the foolishness of men) or the revolutionary (abortion as the reclamation of women's bodily autonomy against patriarchal servitude), to the ghoulish (offering children to the devil) and the truly ghastly acts of witches. Witches are charged with the act of devouring children, of grinding their sinewy flesh and blood into a thick paste to be consumed. We propose to take this particular aspect of the Malleus Maleficarum as a model for our teaching and administrative practice.

It is not uncommon to find that those who teach in philosophy look to Socrates's self-description as a midwife to model their work in the classroom. There is a delicious connection here between this idealised self-image of university teaching many of us hold and the condemnation of witches in the Malleus Maleficarum. As Federici reminds us, Kramer and Sprenger present midwives as "worse than any other woman" (Federici, 2004, p. 183). Why is the male midwife to be idealised, but the female midwife demonised? The daimon that spoke to Socrates provoked him to ask questions, to spur others to wisdom, and so to birth a more stable and just polis. The demons that the witches serve have a more nefarious goal and are unconcerned with redeeming the city. We side, of course, with the demons here, because we live in a world that ought not to exist. While Socrates's practice of philosophy asked deep questions about the nature of things, $t i$ est $i$, the witch is subject to a constructed world of power that is presented as if it were just the nature of things. Federici's study of witch hunts and the ways of living those hunts sought to destroy reveals that the control over biological reproduction wielded by the heretical groups she surveys became a way to experiment with radically different modes of being together, to bring to birth radically different worlds. The university is not such a world, even if it has interstitial spaces where we might imagine such modes of life, or if at times it provides the space and time to create analyses of this world that ought not to exist.

It may be that Socrates was a more nefarious midwife than the now exalted image of him suggests. But Kramer and Sprenger, who appear suspicious of all midwives as potential witches, are clear that midwives practice evil by killing babies after they deliver them. One midwife, they report, confessed to killing more than forty children by sticking pins into their heads and through to their brains (Kramer and Sprenger, 2009, p. 368). They 
consider this to be a greater crime and to cause greater harm than when witches cause impotence or miscarriages. Yet, we hazard that this egregiousness is not because of the difference between blocking procreation and the murder of a born human being; the anxieties of the Malleus Maleficarum are much less empirical. Rather, Kramer and Sprenger are concerned with the appropriation of the Church's proper authority, especially as that power is inseparable from the power of the phallus.

Throughout Kramer and Sprenger's discussions of witches killing or offering babies to the devil there is a consistent focus on the need to surveil women, to make sure that they are never not under the watchful eye of authority. For example, one man becomes suspicious of his wife and daughter when, after giving birth, his wife permits no one but his daughter to come to her. He then hides in order to observe his daughter's actions and discovers that she is, in the guise of carrying out her duties as a midwife, performing witchcraft upon the baby. The father then has both his wife and daughter convicted of sorcery and they are burned together (Kramer and Sprenger, 2009, p. 369). The father in this instance stands in for the power of the phallus, once again raising the problem of the entanglement of the symbolic phallus with gender. In the devouring of children or in offering them to the devil, witches usurp the rule of the phallus and the power of the proper authority. Kramer and Sprenger state this clearly when, drawing upon Thomas Aquinas they say that, 'children are a certain kind of property of the father in their body and slaves and animals are the property of their owners' (Kramer and Sprenger, 2009, p. 373). The concern for children is not a concern for their person, but for the proper authority of the father over his property.

We can see the anxiety over the maintenance of authority at play too in the purposes that Kramer and Sprenger think demons and witches pursue in devouring children and offering them to the devil. For the demons, these acts serve three purposes: to satisfy their arrogance, to make things look as much like holy rites as possible, and to promote the further erosion of the faith by preserving witches who have been dedicated to them from the cradle (Kramer and Sprenger, 2009, p. 371). Authority is threatened in the first instance because the demons flaunt their arrogance before authority. In the second instance, authority is eroded by performing in the material world practices and rites that are similar to those offered by churches and clerics, but which are not controlled by the proper authority. To battle against this misuse of rites and sacraments, Kramer and Sprenger advise not only that women should be surveilled when they meet together, but also that special attention should be paid to how women receive the host during communion (Kramer and Sprenger, 2009, p. 320). Finally, the anxiety present in the last instance returns us to the theme of reproduction, as the inquisitors fear the growth of a population that is not a reproduction of their own.

We must not infantilise our students; in addition to its regular sense this also means that we must not treat students as if we are reproducing ourselves in them. What is it that we would be reproducing? The same structures that we decry at every turn. A university we know to be structurally unequal, built on and for violent and death-dealing distinctions of race, class and gender. A discipline that we know to be too captured by its own concerns to develop and grow in light of new questions that come from outside of it, too concerned with its own self-propagation to worry about the wives and daughters, the teachers and students burned alive for the sake of the children. To teach critical thinking must be to teach our students to think critically about what they are being taught and why, about the inescapable antagonism between the desire to be transformed by learning and the need to meet certain criteria in order to get a degree. ${ }^{6}$ While we cannot and should not refuse the task of passing on to our students the skills that they need to survive in this world, to offer them to devil or even to devour them would mean teaching in such a way that allows them to think beyond the demand to reproduce that world; to teach them what they need to know, but not to believe in it too much.

The current climate is not one in which the reproduction of the university seems guaranteed. The rise of precarity and everintensifying competition in every area of academic life, burgeoning debt crises, and threats to our funding have made many of us fear for the future; for our future and for the future of institutions and positions which, however exploitative, have nonetheless been for many of us a refuge. It is tempting to look longingly back at our ancestral past, to seek to cling to what wealth we have inherited. But we too must resist the temptation to believe too much in the university, which has always been built on and sustained by violence. We cannot offer our children to the devil until we, too, have switched our allegiance.

\section{Exit through the Bestiary}

The anxieties about reproduction we have sketched in this essay spill over into other anxieties, in keeping with the diffuse nature of anxiety. The anxiety about reproduction spills over into anxiety about the maintenance of boundaries, of identities and their attendant purities. In taking a position against the reproduction of Continental philosophy of religion we are taking a position for the impurity of a practice whose name may be continental philosophy of religion. What is called for is the miscegenation of continental philosophy of religion rather than the attempt to secure its purity, a purity that is as illusory as all pure identities are. For Kramer and Sprenger, although it may appear that humans can be turned "into the shape of beasts through the art of conjuring", a man is never truly transmogrified into something other than himself (Kramer and Sprenger, 2009, p. 171). The authors go to great lengths to argue that whatever bodily change appears to have taken place, it is always a matter of demons and witches working to deceive the senses. By way of concluding let us set aside this defensive posture of Kramer and Sprenger, let us reject their claim of the hallucinatory nature of witchcraft and instead think from within those hallucinations as if they were reality. There is good reason to do so, for the world generated by the logic of policing present in the Malleus Maleficarum produces the most dangerous hallucination: of a world that is not experienced as a hallucination. They produce, then, a psychosis, a complete break from reality precisely in their attempt to control that reality. Let us conclude by thinking the miscegenation of thought, the blurring of things into one another.

Within the Malleus Maleficarum there are a number of points where the concern for the purity of identity is displayed, most clearly in the fear of transmogrification from which we have borrowed our overarching model of engaging with the Malleus Maleficarum. That one could be transformed from a man into an animal or that the barrier between life and death could be blurred through 'nigromancy'. This translation choice of Christopher S. Mackay is made to conserve the false etymology of the medieval form of necromancy, which literally means 'corpse divination'. Mackay explains that the medieval form arises from a confusion between the words for blackness and corpse, 'Once knowledge of Greek was lost in Western Europe in the early medieval period, this element was confused with the Latin niger (black)' (Kramer and Sprenger, 2009, p. 56). We remain unconvinced by his claim that this malaprop emerges from an association of the colour of nighttime with evil; Geraldine Heng, amongst many others today working on the question of race in medieval Europe, has shown that the association of blackness with evil extended far beyond the 
nighttime and was explicitly concerned with the racialisation of blackness at least as far back as 1260 (Heng, 2011, p. 259).

Kramer and Sprenger, always taking care to undercut the power of witchcraft as much as they can, claim that nigromancy is not, as is commonly feared, the power to bring the dead back to life but, instead, the conjuring of demons. It is these demons who fool people into thinking they have raised the dead. They do so by taking on the appearance of the deceased person they are trying to summon (Kramer and Sprenger, 2009, p. 243). The last bit of authority is wrested from a man here, for no man can control his identity or defend himself in death. That a demon would take on this appearance creates even more anxiety. The connection here with the way that settler-colonial descendants of white Europeans interpret the blackness of a person is not lost on us here. One need only remember the words of the murderer of the black teenager Michael Brown, 'The only way I can describe it [sic], it [sic] looks like a demon' (State of Missouri v. Darren Wilson, 2014, p. 225).

When considering the construction of the colonial world by European Christians and its extension by European secularists one is struck by the way that creation proceeds through separation or division. In the same way that creation comes to be through the separation of waters from the land, from night and day, so too does the colonial world come to be through the separation of the colonial zone from the native zone (see Fanon, 2004, pp. 1-62), through the separation of the city and the natural world, the domesticated and the wild, the human and the slave (see Wilderson, 2010). Such divisions are constructed but come to be naturalised through being folded into a metaphysical vision of the world and the attendant changes to the social brought about by that vision. Thus, in the white European imaginary, blackness comes to be associated with death and then comes to be associated with act of disrespecting the boundary between life and death, creating a kind of existence as a zombie or living-death. This imaginary, however, becomes a reality for those who come to be enslaved. In order to protect themselves from the evil of blackness, to postpone such a closeness with death, the white European subjects black-skinned Africans to social death, transmogrifying these Africans of various tribes and nations into "black bodies" that exist in a liminal state between life and death. The illusory violence feared in the loss of authority and the sovereignty of the church is visited upon those people who are denied their humanity through the social death of slavery, defined by Orlando Patterson as 'the permanent, violent domination of natally alienated and generally dishonoured persons' (Patterson, 1982, p. 13).

To refuse the reproduction of continental philosophy of religion is to begin to refuse the reproduction of such a world. It would be impossible to simply live as if these boundaries no longer existed. To do so would be to ignore the demands for survival in a world that forces complicity; but it would also be to live as if in an innocence that is illusory. Yet, as philosophers of religion, one can call up the dead and make them give account. These dead may in fact be the demons that are hallucinated by whiteness, but they are demons who in taking on the appearance of the dead make them speak a truth covered over and hidden in the philosophical and theological texts of the dead. We may begin to think of this understanding of the demonic as a way to engage with Black Studies and other radical intellectual practices that call the European tradition of philosophy and the humanities generally to account. To think about the white tradition under the conditions of those scholars and their work in order to make the dead speak anew and to honour those other dead whose lives were made death in their living.

Slaves are placed alongside women, children, and animals, who all exist as the property of men in the Malleus Maleficarum. The division between human and animal begins with ownership, such that those who are owned are not fully human beings, placed instead in the Malleus Maleficarum's bestiary. While many different animals play a role within the Malleus Maleficarum's taxonomy of magic, two beasts take special prominence: the cow and the wolf. This is a clear division of the non-human animal world into the domesticated and the wild. In each instance, whether focusing on the cow or the wolf, the authors consider these animals only in relation to the survival of men and their dependents. The wolf threatens to overpower and kill the man under the power of witches (though sometimes the wolf will kill simply according to its nature-because it is a wolf, rather than because of any magical interference) and the cow threatens to stop giving milk under the direct intervention of witches (Kramer and Sprenger, 2009, p. 315).

Along with the nigromancer, let us take our model for thinking from this closeness to death found also in the couple of the cow and the wolf. The Cathars-a community positioned as heretical by dominant Christian society, and subject to intense persecution and eventually to mass murder-might align with the cow through their refusal to produce. Federici writes of the Cathars that their anti-natalism is part and parcel of their vegetarianism or resistance to participation in the economy of death. "The Cathars', she writes 'also rejected marriage and procreation and were strict vegetarians, both because they refused to kill animals and because they wished to avoid any food, like eggs and meats, resulting from sexual generation' (Federici, 2004, p. 35). This refusal of sexual generation enthralled to the logic of production does not find its roots in puritanical ethics, but rather stems from 'a refusal of life "degraded to mere survival" ' (Federici, 2004, p. 35). So much of intellectual and academic life today is domesticated and subject to the everyday violence of mere survival. The cow, like the Cathar, is well-placed to see the truth of the system, its reliance on death, precisely because the cow only exists in the system to die. To refuse mere survival requires that we be honest and clearsighted about the prospects of freedom and liberation. The cow is domesticated, but refuses to produce.

The wolf is a fearsome animal in the bestiary of the Malleus Maleficarum because the wolf is wild. The wolf threatens the borders of the village and threatens to overpower the strength of the human. The Europe of the Malleus Maleficarum understands itself as threatened from the outside by Islam. In contemplating friendship with the wolf, continental philosophy of religion must embrace the witches' friendship with those who stand as 'wild', as outside the direct control of the Christian-secular world. For Kramer and Sprenger it is in the wolf's nature to eat people; and yet sometimes they do so because of demons (Kramer and Sprenger, 2009, pp. 209-210). Continental philosophy of religion has been largely a Christian-secular enterprise with very little engagement outside of that tradition aside from engagements with European Judaism. This engagement has often been undertaken in a supplementary way, sometimes repeating certain supercessionist tropes from the Christian legacy and a certain domestication of Jewish faith and practice common in the secular division between "good religious" and "bad religious." While the real living tradition of Islam contains its own processes of reproduction, the figure of the Muslim and his or her categorisation in the Christian-secular world delineate him or her as a sinthomosexual.

Lee Edelman has remarked that 'homosexuality, in certain Western democracies, may be shedding (in part) its connection to queerness, continuing the process of normalisation by which it mirrors and so reinforces dominant ideologies of social relation' (Edelman, 2017, p. 125). The queerness that threatens social order is never a given, it never arises from a single act or as a positive identity. Such is the lesson that Leo Bersani takes from Foucault's 
remarks that 'What makes homosexuality "disturbing" is the homosexual mode of life, much more than the sexual act itself' (Foucault, 1997, pp. 136-137); this leads him to critique the easy identification of gay practices with radical politics (see Bersani, 2010 , p. 12). It is in this way that a non-reproductive continental philosophy of religion can and should engage with a tradition like Islam, a tradition like queer theory, and with those who work between and across such traditions. Continental philosophy of religion should engage with them especially in the violent form hallucinated by the West and in the violence that queer Muslims bring to the very unitary vision of Islam and the unitary vision of the LGBTQ community (see El-Tayeb, 2012). There is something to the shared casting of the wolf, the Muslim, and the queer as sinthomosexual which calls for a non-reproductive engagement. For they are all cast as violent 'by nature' in the imaginary of the Christian-secular world. In joining, as witches do, with the violence of the wolf we may begin to think through the decision made in our tradition to see violence when it is directed against the social order of reproduction, and not see the violence that is undertaken to secure and protect the social order of reproduction.

The future is likely to be as violent as the present. The anxiety to protect the reproduction of continental philosophy of religion will not save our colleagues or students from that violence and is in fact generated by violent structures. To give up on our anxiety is to embrace the joy of staying in bed, to stay in the arms of your lover or lovers. Yet we cannot retreat to the privatised and domesticated pleasures of the bourgeois family home. The image of the Witches' Sabbath suggests another way of coming together, of joining with others who similarly cannot afford the future, of shedding one's private identity within a dance, a feast, a frenzy in which the flesh of one is confused for that of another, and where it really does not matter-omnia sunt communia, after all. Let the future come or not; now is the time of pleasure, of getting what we want for nothing.

\section{Data availability}

Data sharing is not applicable to this paper as no datasets were generated or analysed.

Received: 25 September 2018 Accepted: 3 December 2018

Published online: 08 January 2019

\section{Notes}

1 This is a philosophical adaptation of the common charge against witches, that they used their magic for that most unforgivable of all sins: to obtain what they wanted 'without work' (Federici, 2004, p. 142).

2 Laruelle's notion of 'philo-fiction' is developed at length in English in Laruelle (2013, pp. 197-233). Philo-fiction can be understood as the result of the method of nonphilosophy. Non-philosophy aims to disempower what Laruelle sees as philosophy's self-sufficiency or 'arrogance'-its claim to produce truths regarding the Real or the Real's manifestations as phenomena. For Laruelle, philosophy becomes a practice that produces thinking about itself and in so doing confuses itself for the object it aims to know. Philo-fiction becomes a way of conceiving of philosophy undertaken alongside other forms of thought. In this practice we are able to engage with other modes of thought, other forms of knowledge, as if they are already doing philosophy and we can fabulate those thoughts as philosophy. For other examples of this method in practice (see Smith, 2013).

3 See, e.g., Mill (1869), 'Those who are still in a state to require being taken care of by others must be protected against their own actions as well as against external injury'.

4 Examples abound; see, e.g., Crockett et al. (2014); Joy (2011); Baker and Maxwell (2003); Smith and Whistler (2010); Smith (2009) and the 2017 American Academy of Religion panel on 'Reframing the Continental Philosophy of Religion' out of which this paper emerged.
5 As a recent email from one of the author's institutions pointed out, for example, the funding body Research England ' "has identified new priorities towards which our spending must be directed", including, "addressing the needs of local innovative business", and "spin outs and start ups"'.

6 For example, one of the authors opens her first year introductory module by asking students to think about the different people and institutions who have a stake in their education and where there are conflicts between, for example, what the government, their families, their lecturers and they themselves want them to get out of their degree. On the administrative side of things, the other author has been part of a redesign of mandatory assessment within his department so as to create opportunities for adjunct faculty to use the assessment process to ask for resources which would improve their working conditions.

\section{References}

State of Missouri v. Darren Wilson (2014) V (Grand Jury)

Ahmed S (2016) Speaking out. feministkilljoys. https://feministkilljoys.com/2016/ 06/02/speaking-out/. Accessed 24 Sept 2018

Anidjar G (2014) Blood: a critique of christianity. Columbia University Press, New York

Baker D-P, Maxwell P (2003) Explorations in contemporary continental philosophy of religion. Rodopi, Amsterdam

Barber D (2011) On diaspora: christianity, religion, and secularity. Cascade Books, Eugene

Barber D (2016) World-making and grammatical impasse. Qui Parle 25(12):179-206

Bersani L (2010) Is the rectum a grave? and other essays. The University of Chicago Press, Chicago

Bousquet M (2008) How the university works: higher education and the low-wage nation. NYU Press, New York

Brown W (2015) Undoing the demos: neoliberalism's stealth revolution. Zone Books, New York

Chu AL (2018) I worked with Avital Ronell. I believe her accuser. The Chronicle of Higher Education. https://www.chronicle.com/article/I-Worked-With-AvitalRonell-I/244415, Accessed 14 Dec 2018

Crockett C, Putt BK, Robbins JW (eds) (2014) The future of continental philosophy of religion. Indiana University Press, Indianapolis

Dubilet A (2019) The self-emptying subject: Kenosis and Immanence, medieval to modern. Fordham University Press, New York

Edelman L (2004) No future: Queer theory and the death drive. Duke University Press, Durham and London

Edelman L (2017) Learning nothing: bad education. Differ: A J Fem Cult Stud 28 (1):124-173

El-Tayeb F (2012) 'Gays who cannot properly be gay': Queer Muslims in the Neoliberal European City. Eur J Women's Stud 19(1):79-95

Fanon F (2004) The wretched of the earth. Grove Press, New York, Translated by Philcox, R

Federici S (2004) Caliban and the witch: women, the body and primitive accumulation. Autonomedia, Brooklyn

Foucault M (1997) Friendship as a Way of Life. In: Rainbow P (ed) Ethics/Subjectivity and truth (Essential works of Foucault 1954-1984), vol 1. The New Press, New York

Goodchild P (ed) (2002) Rethinking philosophy of religion: approaches from continental philosophy. Fordham University Press, New York

Grove J (2015) Warwick v-c Nigel Thrift recorded calling student protestors 'yobs'. Times Higher Education. https://www.timeshighereducation.com/news/ warwick-v-c-nigel-thrift-recorded-calling-student-protesters-yobs/2019163. article. Accessed 11 July 2018

Heng G (2011) The invention of race in the European middle ages I: race studies, modernity, and the middle ages 1. Lit Compass 8(5):258-274

Irigaray L (1985) Speculum of the other woman. (Trans: Gill GC). Cornell University Press, Ithaca

Joy M (ed) (2011) Continental philosophy and philosophy of religion. Springer, New York

Kramer H, Sprenger J (2009) The hammer of witches: a complete translation of the Malleus Maleficarum. (Trans: Mackay C). Cambridge University Press, Cambridge

Kundnani A (2015) The Muslims are coming!: Islamophobia, extremism, and the domestic war on terror. Verso, London

Lacan J (2006) Écrits. (Trans: Fink B). W.W. Norton \& Company, New York

Laruelle F (2013) Anti-Badiou: on the introduction of Maoism into philosophy. (Trans: Mackay R). Bloomsbury, London

Lister R, Armstrong K, Hillyard P et al. (2015) Prevent will have a chilling effect on open debate, free speech and political dissent. The Independent. https://www. independent.co.uk/voices/letters/prevent-will-have-a-chilling-effect-on-opendebate-free-speech-and-political-dissent-10381491.html. Accessed 18 Nov 2018

Marx K, Engels F (1998) A critique of the German ideology. Prometheus Books, Amherst 
Mill JS (1869) On liberty. https://www.bartleby.com/130/1.html. Accessed 11 July 2018

Moten F, Harney S (2004) The undercommons: fugitive planning and black study. Minor Compositions, New York

Moore RI (1987) The formation of a persecuting society: authority and deviance in Western Europe. Basil Blackwell, Oxford, p 950-1250

Nancy J-L (2018) Clear Confusion. Theory illuminati. https://theoryilluminati. com/texts-and-contexts/f/clear-confusion. Accessed 19 Sep 2018

Pateman C (1988) The sexual contract. Polity, Cambridge

Patterson O (1982) Slavery and social death: a comparative study. Harvard University Press, Cambridge

Payne FM (2018) Long read: the Badger's Tickell interview revisited amidst UCU strikes. The Badger. http://thebadgeronline.com/2018/03/long-read-badgerstickell-interview-revisited-amidst-ucu-strikes. Accessed 11 July 2018

Rigg D (2018) We are all Jim Newell Now: Academics Support Sacked Salford Professor. The Sphinx. https://www.thesphinx.co.uk/2018/08/we-are-all-jimnewell-now-academics-support-sacked-salford-professor/. Accessed 24 Sep 2018

Rose M (2019) A theology of failure: Žižek against christian innocence. Fordham University Press, New York

Smith AP (2013) A non-philosophical theory of nature: ecologies of thought. Palgrave Macmillian, New York

Smith AP, Whistler D (eds) (2010) After the postsecular and the postmodern: new essays in continental philosophy of religion. Cambridge Scholars Press, Newcastle

Smith JKA (2009) Continental philosophy of religion. Faith Philos 26(4):440-448

Wilderson III F (2010) Red, white, and black: cinema and the structure of U.S. Antagonisms. Duke University Press, Durham

Wynter S (1994) 1492: A new world view. In: Hyatt VL, Nettleford R (eds) Race, discourse and the origin of the Americas: a new world view. Smithsonian Institution Press, Washington, DC

\section{Additional information}

Competing interests: The authors declare no competing interests.

Reprints and permission information is available online at http://www.nature.com/ reprints

Publisher's note: Springer Nature remains neutral with regard to jurisdictional claims in published maps and institutional affiliations.

\section{(c) (i)}

Open Access This article is licensed under a Creative Commons Attribution 4.0 International License, which permits use, sharing, adaptation, distribution and reproduction in any medium or format, as long as you give appropriate credit to the original author(s) and the source, provide a link to the Creative Commons license, and indicate if changes were made. The images or other third party material in this article are included in the article's Creative Commons license, unless indicated otherwise in a credit line to the material. If material is not included in the article's Creative Commons license and your intended use is not permitted by statutory regulation or exceeds the permitted use, you will need to obtain permission directly from the copyright holder. To view a copy of this license, visit http://creativecommons.org/ licenses/by/4.0/.

(C) The Author(s) 2019 